\title{
Transmission and Epidemiology of Hepatitis E Virus Genotype 3 and 4 Infections
}

\author{
Harry R. Dalton ${ }^{1,2}$ and Jacques Izopet ${ }^{3,4}$ \\ ${ }^{1}$ Royal Cornwall Hospital, Truro TR1 3LJ, United Kingdom \\ ${ }^{2}$ European Centre for Environment and Human Health, University of Exeter, Truro TR1 3LJ, United Kingdom \\ ${ }^{3}$ Department of Virology, Hepatitis E Virus National Reference Centre, Toulouse University Hospital, 31059 \\ Toulouse, France \\ ${ }^{4}$ Toulouse-Purpan Centre for Pathophysiology, INSERM UMR1043/CNRS UMR 5282, CPTP, Toulouse \\ University Paul Sabatier, 31024 Toulouse, France \\ Correspondence: hardalton@gmail.com
}

Following the introduction of robust serological and molecular tools, our understanding of the epidemiology of zoonotic hepatitis E virus (HEV) has improved considerably in recent years. Current thinking suggests that consumption of pork meat products is the key route of infection in humans, but it is certainly not the only one. Other routes of infection include environmental spread, contaminated water, and via the human blood supply. The epidemiology of HEV genotype (gt)3 and gt 4 is complex, as there are several sources and routes of infection, and it is likely that these vary between and within countries and over time.

Electron microscopic studies led to the discovEery of hepatitis E virus (HEV) in 1983 (Balayan et al. 1983) and the HEV genome was characterized in the early 1990s (Reyes et al. 1990; Tam et al. 1991). From then until 2005, $\mathrm{HEV}$ infections were considered to be endemic only in developing countries in Asia, Africa, and Central America, although HEV infections in developed countries were believed to be acquired while traveling in areas where epidemics and sporadic cases occurred. This perception was incorrect as was shown by the discovery of a swine HEV strain (now classified in HEV genotype [gt]3) that was closely related to human HEV strains. The zoonotic potential of this virus (Meng et al. 1997, 1998) was confirmed by re- ports of sporadic cases of locally acquired HEV in industrialized European countries and the United States. These cases were linked to the presence of large reservoirs of virus in animals such as pigs (Mansuy et al. 2004; Amon et al. 2006; Dalton et al. 2008a; Lewis et al. 2008). The availability of powerful serological and molecular tools within the last decade, plus large studies on blood donors from several countries, has greatly improved our understanding of the epidemiology and transmission of HEV in developed countries.

HEV is a small RNA virus with an icosahedral capsid (see Kenney and Meng 2018). There are two forms of infectious particles: the nonenveloped and quasi-enveloped forms (Feng

Editors: Stanley M. Lemon and Christopher Walker

Additional Perspectives on Enteric Hepatitis Viruses available at www.perspectivesinmedicine.org

Copyright (C) 2018 Cold Spring Harbor Laboratory Press; all rights reserved; doi: 10.1101/cshperspect.a032144

Cite this article as Cold Spring Harb Perspect Med 2018;8:a032144 
H.R. Dalton and J. Izopet

et al. 2014). The virions found in the feces ( 27 to $34 \mathrm{~nm}$ in diameter) have no envelope, although the virions circulating in the blood are cloaked in host cell membranes (50 to $110 \mathrm{~nm}$ in diameter) (Takahashi et al. 2010; Yin et al. 2016; Chapuy-Regaud et al. 2017). The HEV genome, a single-stranded positive-sense RNA $\sim 7.2 \mathrm{~kb}$ long, consists of a short $5^{\prime}$ noncoding region that is capped with 7-methylguanosine, three open reading frames (ORFs), ORF1, ORF2, and ORF3, and a short $3^{\prime}$ noncoding region that ends in a poly-(A) tail. ORF1 encodes a nonstructural polyprotein with several functional domains involved in HEV RNA replication. ORF2 encodes the viral capsid protein and ORF3 encodes a small protein that is essential for viral egress. HEV gt 3 and HEV gt 4 are classified within the Orthohepevirus A species, Orthohepevirus genus, Hepeviridae family (see www.ictvonline.org/virustaxonomy). The Orthohepevirus A species includes seven genotypes (HEV gt1 to gt7) but only one serotype is recognized. Unlike HEV gt1 and gt2, which are obligate human pathogens circulating in developing countries, gt 3 and gt 4 have an animal reservoir and infect humans in developed countries. HEV gt5, gt6, and gt7 viruses are known to infect animals such as wild boar and camels. HEV gt7 was recently found to be responsible for a severe infection in a person who had consumed camel milk and meat (Lee et al. 2016).

\section{VIROLOGICAL TOOLS FOR SCREENING, DIAGNOSIS, AND EPIDEMIOLOGICAL STUDIES}

Most acute zoonotic HEV infections are asymptomatic (Fig. 1), but any symptoms that do develop are similar to those attributed to other causes of hepatitis. Typically, an initial incubation period of 2 to 6 weeks precedes an increase in serum alanine aminotransferase (ALT) activity. HEV infections can be diagnosed indirectly by detecting anti-HEV antibodies in the serum, or directly by detecting HEV RNA or capsid antigen in the blood or other body fluids. The immunoglobulin (Ig)M response is usually detected around the time the ALT increases and persists for 6-9 months. The IgG response is frequently delayed; it peaks $\sim 4$ weeks later and persists for several years although the exact duration of this response remains uncertain. HEV RNA becomes detectable in the blood and stools during the incubation period and persists for $\sim 4$

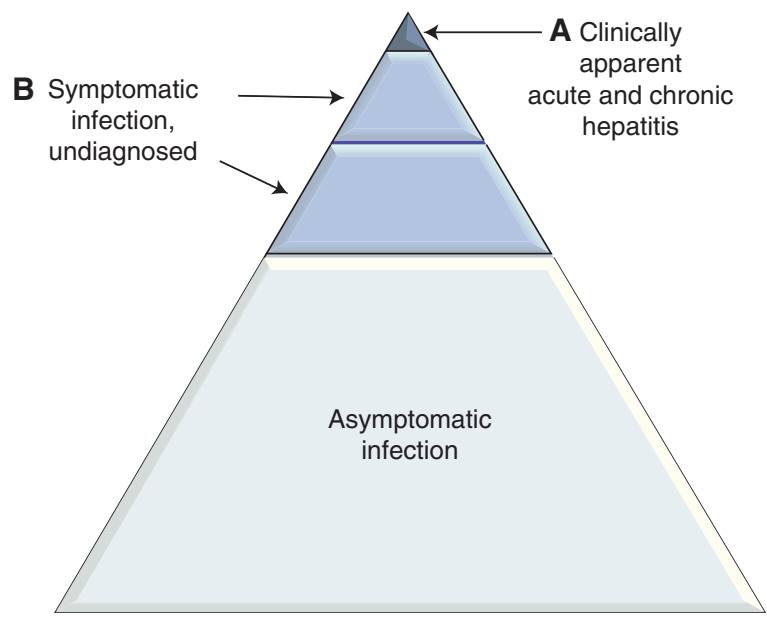

Figure 1. Symptomatic and asymptomatic hepatitis E virus (HEV). More than $90 \%$ of infections with HEV genotype (gt) 3 and gt 4 are asymptomatic. Only a small minority of patients (mainly older males) develops symptomatic hepatitis $(A)$. Other patients are symptomatic, but currently not diagnosed $(B)$. These include patients who present with primarily a neurological illness. The numerical relationship between $A$ and $B$ is unclear. 
weeks in the blood and for 6 weeks in the feces. Capsid antigen persists in the blood for about the same length of time.

\section{Serology}

Most commercial assays for detecting antiHEV IgM and IgG are microplate-based enzyme immunoassays. Multiparametric automated instruments are also in development (Abravanel et al. 2017a). Immunochromatographic tests allowing simple, rapid diagnosis have also been developed (Abravanel et al. 2015; Pisanic et al. 2017). IgG and IgM immunoblot assays are available, but their clinical relevance has not been established, owing to their lack of sensitivity (Schnegg et al. 2013; Cattoir et al. 2017). Although antigens used in most HEV immunoassays are based on recombinant or synthetic peptides based on ORF2/ORF3 from an HEV gt1 strain, several studies have shown that they are reactive with antibodies in HEV gt3- and gt4-infected individuals (Legrand-Abravanel et al. 2009b; Pas et al. 2013; Schnegg et al. 2013).

The presence of anti-HEV IgM in the serum is a key marker of an acute infection. Follow-up studies of patients shown to have acute hepatitis $\mathrm{E}$ by nucleic acid testing indicate that anti-HEV IgM persists for more than 6 months (Wen et al. 2015). Several studies using different serum panels have compared the performance of IgM assays (Drobeniuc et al. 2010; Avellon et al. 2015; Norder et al. 2016; Vollmer et al. 2016b). But it is difficult to compare their findings because differences in assay performance may be related to different versions of the test used (Avellon et al. 2015). Five IgM assays were compared using sera from immunocompetent and immunocompromised individuals with a proven $\mathrm{HEV}$ infection (positive HEV RNA) (Norder et al. 2016). Only 71\% of the results from all the assays were concordant. There were also discrepancies when single samples from 10 seroconversion panels were assayed (Vollmer et al. 2016b). Abravanel et al. showed that the IgM assays frequently used in Europe are extremely specific ( $>99.5 \%$ ); their sensitivities were $98 \%$ for immunocompetent patients and $85 \%-87 \%$ for immunocompromised patients with a validated polymerase chain reaction (PCR) assay as reference (Abravanel et al. 2013). A study on 10 blood donors with clinically asymptomatic HEV gt3 infections found that the mean time before HEVspecific antibodies could be detected was 31 days for both IgM and IgA, and these subjects remained seropositive for 69 days $(\operatorname{IgM})$ and 80 days (IgA) (Vollmer et al. 2016a). Studies on 15 Japanese patients with acute symptomatic hepatitis $\mathrm{E}$ found that both anti-HEV IgM and anti-HEV IgA were detected at about the same time as in asymptomatic cases, but they remained detectable for much longer, until the end of the observation period (Takahashi et al. 2005). Although most commercial assays used to diagnose acute HEV infections are IgM assays, IgA assays are used in Japan in this setting.

The presence of anti-HEV IgG alone indicates a past infection. The limits of detection of commercial anti-HEV IgG assays vary from $0.25 \mathrm{WHO}$ units/mL to $2.5 \mathrm{WHO}$ units/mL (World Health Organization [WHO] reference reagent established in 2002; National Institute for Biological Standards and Control Code 95/ 484). As expected, comparative evaluations of IgG assays have shown a wide variation in assay sensitivity and specificity (Avellon et al. 2015; Norder et al. 2016; Vollmer et al. 2016b). This makes it difficult to interpret published studies on anti-HEV IgG seroprevalence. The use of more sensitive IgG assays has led to threefold to fourfold increases in the estimates of seroprevalence (Bendall et al. 2008, 2010; Mansuy et al. 2011; Wenzel et al. 2013). A meta-analysis of studies performed in Europe found that the seroprevalence depended primarily on the IgG assay used (Hartl et al. 2016a). However, a clearer picture of HEV epidemiology in industrialized countries was obtained using a single, specific, sensitive assay (detection limit: 0.25 WHO units $/ \mathrm{mL}$ ) to test large populations of blood donors from different geographical areas (Kamar et al. 2014a).

The level of anti-HEV IgG that prevents infection could be defined by determining the serum anti-HEV IgG concentration. A vaccine 
H.R. Dalton and J. Izopet

study suggested that an antibody concentration of $2.5 \mathrm{WHO}$ unit/mL provided protection (Shrestha et al. 2007), but there have been reports of reinfections of immunocompromised patients with higher antibody concentrations (up to 7 WHO unit/mL) (Abravanel et al. 2014). Others have also observed the reinfection of immunocompetent individuals (ServantDelmas et al. 2016; Schemmerer et al. 2017).

\section{Viral RNA Detection, Quantification, and Characterization}

Immunocompromised patients should be tested for HEV RNA because their immune response is impaired, and a negative IgM test does not exclude an HEV infection. In addition, a chronic $\mathrm{HEV}$ infection is defined by the persistence of HEV RNA for at least 3 months (Kamar et al. 2013). HEV RNA can be detected in the blood, stools, and other body compartments using nucleic acid amplification technologies with primers targeting regions of the genome that are conserved between HEV genotypes and subgenotypes. The assays must all be validated using the WHO international standard for HEV RNA (Baylis et al. 2013). The limit of detection of current assays is 7 to $80 \mathrm{IU} / \mathrm{mL}$. Most "homebrew" and commercial assays are based on real-time PCR and target ORF3 (Abravanel et al. 2012, 2013). Fully automated platforms based on real-time PCR or transcription-mediated amplification (TMA) assays are now available for high-throughput qualitative testing (Sauleda et al. 2015; Gallian et al. 2017). Conversely, small systems based on loop-mediated isothermal amplification (LAMP) assays provide a rapid one-step, single-tube amplification of HEV RNA (Lan et al. 2009).

HEV RNA should also be quantified for pathophysiological studies and for monitoring the HEV virus loads of chronically infected patients on antiviral therapy (Kamar et al. 2010, 2014b). HEV RNA is usually quantified by realtime PCR assays and a standard curve generated with plasmids or transcripts. The results obtained with different techniques can vary widely (Baylis et al. 2011), highlighting the need for rigorous validation. A newly developed method for quantifying HEV RNA based on reverse transcription droplet digital PCR (RT-ddPCR) was found to perform very well for several different HEV genotypes (Nicot et al. 2016). This method, which does not require a standard curve and reports absolute quantities of HEV RNA, is clearly a promising tool for standardizing HEV RNA assays of blood, food products, and water samples.

HEV RNA sequence data are also useful for molecular epidemiology studies and for tracing the source of an individual's infection or identifying the mutations in the polymerase of the virus infecting a patient for whom ribavirin therapy has failed (Debing et al. 2014, 2016; Lhomme et al. 2015). HEV genotypes and subgenotypes can be determined by sequencing different regions of the HEV genome such as ORF2 or the ORF1 polymerase (RdRp) region (LegrandAbravanel et al. 2009a). A set of reference sequences based on complete genomes was recently proposed (Smith et al. 2016). Next-generation sequencing technologies can interrogate the entire genome of virus strains, as well as describe the spectrum of variants in a particular host.

\section{Antigen Detection}

HEV infections can be diagnosed using a commercial immunoassay to detect the HEV capsid antigen in blood (Zhao et al. 2015; Behrendt et al. 2016; Geng et al. 2016; Tremeaux et al. 2016). Circulating HEV capsid antigen consists of secreted glycoproteins that are not associated with infectious particles. Although less sensitive than nucleic acid testing for detecting an infection, HEV capsid antigen assays perform well and are technically simpler and less expensive than nucleic acid assays (Tremeaux et al. 2016). Capsid antigen concentration could be used to differentiate between acute and chronic infections in acutely infected immunocompromised patients (Behrendt et al. 2016).

\section{TRANSMISSION OF HEV GENOTYPES 3 AND 4}

HEV gt3 and gt4 are mainly transmitted to humans enterically from an animal reservoir con- 
Epidemiology of HEV Genotype 3 and 4 Infections

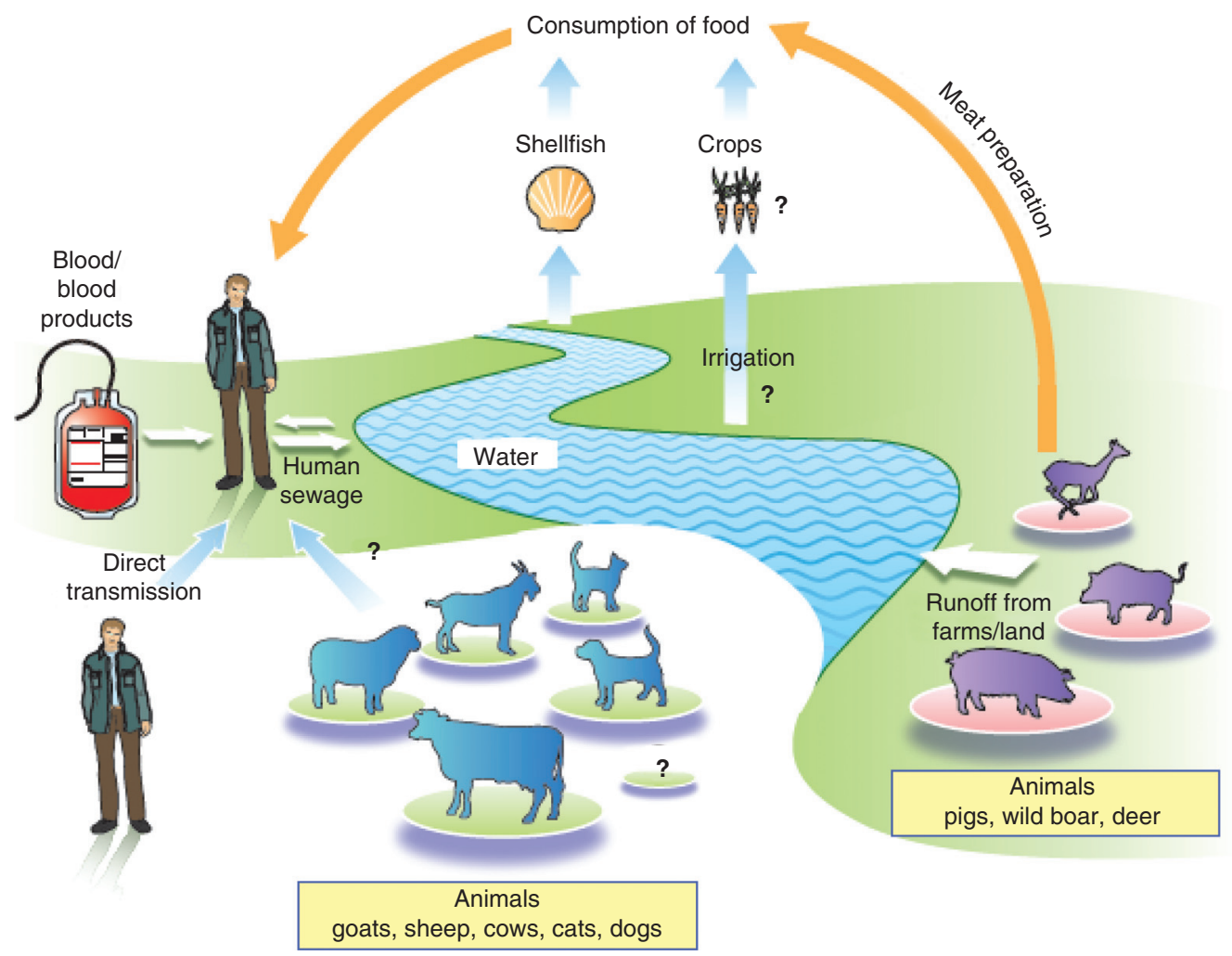

Figure 2. Sources and routes of infection of zoonotic hepatitis E virus (HEV).

sisting primarily of infected pigs, wild boar, deer, and rabbits. This zoonosis can be foodborne, waterborne, or transmitted by direct contact with infected animals. Parenteral transmission is also increasingly recognized; it is by nature iatrogenic (Fig. 2). Only rarely are HEV gt3 and gt 4 transmitted via other routes.

\section{Enteric Foodborne Transmission}

The consumption of uncooked or undercooked infected pork or game is probably the major route by which humans become infected with HEV gt3 or gt4. Several studies in different countries (Japan, Spain, France) have used genetic analysis to obtain direct evidence of zoonotic transmission; they found the same virus strain in the infected subjects and in the remains of animal products they had consumed (Tei et al. 2003; Li et al. 2005; Renou et al. 2014; RiveiroBarciela et al. 2015). Additional evidence came from studies linking sporadic cases or small outbreaks of HEV with the consumption of raw or undercooked pork or wild boar products ( $\mathrm{Ta}-$ mada et al. 2004; Colson et al. 2010; Guillois et al. 2016). Dietary habits are also a risk factor for autochthonous HEV infection and HEV seroprevalence. In Germany, the consumption of wild boar meat and offal has been associated with HEV infection (Wichmann et al. 2008). Similarly, in France, eating pork meat, pork liver sausages, game meat, and offal have been associated with HEV seroprevalence (Mansuy et al. 2016). Both HEV gt 3 and gt 4 RNA have been detected throughout the pork food chain worldwide; studies using cell systems and the experimental inoculation of pigs have revealed infectious virus (Doceul et al. 2016). Most recently, in a study of Dutch blood donors, meat eaters had a significantly higher seroprevalence $(20.5 \%)$ compared with vegetarians $(12.4 \%$; Slot et al. 2017). HEV shed by infected animals, either 
H.R. Dalton and J. Izopet

wild or involved in agricultural practices, can contaminate watercourses, leading to the accumulation of HEV in fruit, vegetables, and shellfish (Doceul et al. 2016). HEV RNA has been detected on red fruit, strawberries, salad vegetables, and spices, and even in oysters and mussels (Doceul et al. 2016). Clearly, foods other than animal products are possible sources of foodborne transmission; there was an outbreak of HEV on a cruise ship after consumption of contaminated mussels (Said et al. 2009).

\section{Waterborne Transmission}

HEV gt3 and gt4 RNAs have been detected in untreated wastewater, pig manure slurry storage facilities, and river water worldwide (Kasorndorkbua et al. 2005; McCreary et al. 2008; La Rosa et al. 2010). Monitoring human enteric viruses in wastewater in France revealed the presence of the major HEV gt3 subtypes circulating in the community (Bisseux et al. 2018). Experimental inoculations of pigs showed that the virus in these aqueous environments was infectious (Kasorndorkbua et al. 2005). A recent meta-analysis found that environmental exposure is an independent risk factor predicting HEV seropositivity (Hartl et al. 2016b). A seroprevalence study performed in France found that consuming infected meat accounted for only $8.6 \%$ of the observed variability in antiHEV IgG, although drinking bottled water was associated with a lower risk of HEV exposure (Mansuy et al. 2016). Another study that focused on the southwest of France also suggested that waterborne transmission could explain local differences in seroprevalence (Mansuy et al. 2015), and reports from the United Kingdom suggest that cases of hepatitis E cluster around the coast (Hunter et al. 2016). A recent study from China described a tap water-mediated HEV gt4 outbreak in a nursing home (Chen et al. 2016).

\section{Direct Contact with Infected Animals}

There have been at least two cases in France in which HEV transmission from an infected animal was supported by molecular evidence, one caused by frequent contact with a pet pig ( $\mathrm{Re}$ nou et al. 2007) and the other during surgical training with a pig (Colson et al. 2007). In addition, IgG is more seroprevalent in French, Dutch, and Swedish workers and veterinarians who work with pigs, as well as among French hunters and forestry workers in France and Germany (Doceul et al. 2016).

\section{Parental, Transfusion-Transmitted HEV}

Transmission of HEV by transfusion has been reported in Japan (HEV gt3 and gt4) (Matsubayashi et al. 2004, 2008; Tamura et al. 2007; Satake et al. 2017) and in several European countries (HEV gt3), including France (HaimBoukobza et al. 2012; Coilly et al. 2013; Hauser et al. 2014; Mallet et al. 2016a), the United Kingdom (Boxall et al. 2006; Hewitt et al. 2014), Germany (Huzly et al. 2014), and Spain (Riveiro-Barciela et al. 2017). Most cases of transfusion-transmitted HEV infection are asymptomatic, as are cases of enteric transmission (Hewitt et al. 2014; Satake et al. 2017). The main risk for immunocompromised patients, the largest group of transfusion recipients, is the persistence of an HEV gt 3 or gt 4 infection leading to chronic hepatitis, rapidly progressing fibrosis, and cirrhosis.

The prevalence of antibodies to HEV and frequency of HEV viremia in blood donors in industrialized countries have turned out to be higher than expected, indicating that zoonotic $\mathrm{HEV}$ infections are very common in the general population. Three levels of endemicity were identified using a sensitive, validated IgG assay: low (anti-HEV IgG $<10 \%$ ), intermediate (antiHEV IgG 10\%-20\%), and high (anti-HEV IgG $>20 \%$ ) (Petrik et al. 2016). The IgG seroprevalence is $22.4 \%$ in France (Mansuy et al. 2016), $27 \%$ in the Netherlands (Slot et al. 2013), 29.5\% in Germany (Vollmer et al. 2012), and 32.6\% in China (Guo et al. 2010). As expected, HEV viremia is more frequently detected by nucleic acid testing in countries where the seroprevalence of IgG is higher (1:600-1:2671) than in other countries (Table 1). Estimates of the prevalence of HEV viremia within a country may differ depending on the nucleic acid testing 
Epidemiology of HEV Genotype 3 and 4 Infections

Table 1. Hepatitis E virus (HEV) seroprevalence and viremia in blood donors in developed countries

\begin{tabular}{|c|c|c|c|}
\hline Country & $\begin{array}{l}\text { HEV immunoglobulin } \\
\text { G (IgG) seroprevalence }\end{array}$ & HEV RNA positive & References \\
\hline \multicolumn{4}{|c|}{ Highly endemic countries } \\
\hline The Netherlands & $27.0 \%$ & $\begin{array}{r}1: 2671 \\
1: 600\end{array}$ & $\begin{array}{l}\text { Slot et al. } 2013 \\
\text { Zaaijer } 2015\end{array}$ \\
\hline France & $22.4 \%$ & $\begin{array}{r}1: 2218 \\
1: 744\end{array}$ & $\begin{array}{l}\text { Mansuy et al. } 2016 \\
\text { Gallian et al. } 2014 \\
\text { Gallian et al. } 2017\end{array}$ \\
\hline Germany & $29.5 \%$ & $1: 1200$ & Vollmer et al. 2012 \\
\hline China & $32.6 \%$ & $1: 1493$ & Guo et al. 2010 \\
\hline \multicolumn{4}{|c|}{ Low/intermediate endemic countries } \\
\hline England & $\begin{array}{l}12.2 \% \\
16 \% \\
12 \%\end{array}$ & $\begin{array}{l}1: 2848 \\
1: 7000\end{array}$ & $\begin{array}{l}\text { Hewitt et al. } 2014 \\
\text { Ijaz et al. } 2012 \\
\text { Beale } 2011\end{array}$ \\
\hline Scotland & $4.7 \%$ & $1: 14520$ & Cleland et al. 2013 \\
\hline Ireland & $5.3 \%$ & $1: 5000$ & O’Riordan et al. 2016 \\
\hline Denmark & & $1: 2330$ & Harritshoj 2016 \\
\hline Sweden & & $1: 7986$ & Baylis et al. 2012 \\
\hline Austria & $13.5 \%$ & $1: 8416$ & Fischer et al. 2015 \\
\hline Spain & $19.9 \%$ & $1: 3333$ & Sauleda et al. 2015 \\
\hline United States & $16 \%$ & 1:9500 & $\begin{array}{l}\text { Xu et al. } 2013 \\
\text { Stramer et al. } 2016\end{array}$ \\
\hline Australia & $6 \%$ & $\begin{array}{r}- \\
1: 14799 \\
1: 74131\end{array}$ & $\begin{array}{l}\text { Shrestha et al. } 2014 \\
\text { Shrestha et al. } 2016 \text { a; } \\
\text { Hoad et al. } 2017\end{array}$ \\
\hline New Zealand & $4 \%$ & & Dalton et al. 2007 \\
\hline Fiji & $2 \%$ & & Halliday et al. 2014 \\
\hline Japan & & $\begin{array}{r}1: 8173 \\
1: 15075\end{array}$ & Minagi et al. 2016 \\
\hline
\end{tabular}

strategy used (limit of detection for molecular techniques, testing individual or pooled samples, pool size). HEV viremia was initially estimated to be present in 1 of 2218 French blood plasma donations when tested in pools of 96 samples (Gallian et al. 2014), but more recent tests of individual units indicate that it is $1 / 744$ (Gallian et al. 2017). This high frequency of $\mathrm{HEV}$ viremia is in line with the IgM anti-HEV seroprevalence in France (1\%) (Mansuy et al. 
2016), considering that HEV viremia persists for $\sim 8$ weeks, which is shorter than the persistence of IgM after an acute HEV infection.

HEV can be transmitted by transfusion of red blood cells, platelets, platelet preparations, pooled granulocytes, and fresh frozen plasma (solvent-detergent-treated, amotosalen-treated, and secured by quarantine). However, there have been no reports of HEV transmission in plasma-derived products.

A 2012-2013 retrospective study screened 225,000 English blood donors for HEV RNA (mini-pools of 24 donations). Follow-up of 43 recipients given infected blood components indicated that 18 (42\%) had had an HEV infection (Hewitt et al. 2014). A high virus load in the donation rendered infection more likely. The risk of transmission was also influenced by the volume of plasma transfused in the final blood component. Subsequent analyses showed that the lowest infective dose of virus was $2 \times 10^{4}$ IU, and that $55 \%$ of the components containing this dose transmitted an infection (Tedder et al. 2017). Another analysis of 19 Japanese cases of transfusion-transmitted $\mathrm{HEV}$ infection found that the minimum infectious dose was $3.6 \times$ $10^{4} \mathrm{IU}$ and that the rate of infection was $50 \%$ (Satake et al. 2017). Other published data suggest that the lowest infectious dose that transmits HEV infection is $7.1 \times 10^{3} \mathrm{IU}$ (Huzly et al. 2014).

The presence of specific antibodies in the donor or the recipient may also influence the risk of transmission. Although the U.K. study reported that the absence of detectable antibodies in the donor made infection more likely (Hewitt et al. 2014), statistical analysis and a subsequent report indicated that the proportions of seropositive donors in the transmitting (4/18) and nontransmitting (8/25) groups were similar (Tedder et al. 2017). The U.K. study did not evaluate the influence of specific antibodies in the recipient (Hewitt et al. 2014). Both immunocompromised and immunocompetent patients have been reinfected (Abravanel et al. 2014; Servant-Delmas et al. 2016; Schemmerer et al. 2017). Experimental studies showed that the neutralizing capacity of specific antibodies directed against the HEV capsid protein is in- hibited because the HEV circulating in the blood is associated with lipids (Chapuy-Regaud et al. 2017).

A transfusion recipient is also subject to dietary and environmental risks. Estimates based on the U.K. population, where the annual seroconversion rate is $0.2 \%$, indicate that the transfusion risk of infection only exceeds the annual dietary risk when $>13$ individual donor components are transfused (Tedder et al. 2017). Allograft stem cell recipients who may be exposed to blood components from many different donors could be most likely to acquire an infection. But the risks from dietary and environmental exposure far exceed that of transfusion for many recipients. A French study found that only $3 / 60$ (5\%) of HEV-infected transplant recipients had been infected by transfusion-transmitted virus (Lhomme et al. 2017).

\section{Solid Organ Transplants and Progenitor Stem Cells}

HEV can also be transmitted during liver transplantation. In one case study (Schlosser et al. 2012), a recipient of an HEV-infected liver from a donor with occult $\mathrm{HEV}$ infection rapidly developed graft cirrhosis and died from decompensated liver disease. HEV infections were also transmitted via renal grafts given to two recipients (Pourbaix et al. 2017). Last, hematopoietic stem cell (HSC) donors have been shown to harbor HEV infections (Koenecke et al. 2014; Frange et al. 2015; O'Donghaile et al. 2017), although no case of HSC transplantation-related HEV transmission has been reported to date.

\section{Other Modes of Transmission}

Person-to-person transmission of an HEV infection seems to be rare. However, this may have occurred for HEV gt1 during an outbreak in Uganda (Teshale et al. 2010). There was also an initial small outbreak on a French island caused by the guests at a wedding all eating contaminated grilled pig meat; subsequent investigation showed an association between the number of hepatitis $\mathrm{E}$ cases in the community and the concentration of HEV gt 3 detected in sewage 
(Miura et al. 2016). A study of HEV infection in French HIV-infected patients found no evidence that HEV is transmitted sexually (Abravanel et al. 2017b).

\section{Nosocomial Transmission}

Excluding transfusion and solid organ transplantation, nosocomial transmission of HEV infection is unusual. However, molecular studies have provided evidence of this rare event in a hematology ward in France (Mansuy et al. 2009). The index case became infected after coming in contact with an undiagnosed, chronically infected patient treated in the same unit.

\section{Mother-to-Child Transmission}

Although HEV gt1 infection during pregnancy is associated with a severe maternal clinical outcome and can be transmitted to the fetus and infant, pregnant women infected with HEV gt3 and gt 4 do not suffer these complications (Andersson et al. 2008; Anty et al. 2012; Tabatabai et al. 2014). The mechanistic aspects of this genotype-specific pathogenicity and mother-tochild transmission are unknown.

\section{GEOGRAPHICAL DIFFERENCES IN THE PREVALENCE OF HEV gt3 AND gt4}

\section{Europe}

Our understanding of the worldwide epidemiology of HEV gt 3 and gt 4 is incomplete, but is best documented in Western Europe. Human cases are nearly all caused by HEV gt3 (Dalton et al. 2008a; Kamar et al. 2012, 2014a), but there have been occasional sporadic cases as well as small clusters caused by HEV gt4 (Bouamra et al. 2014). The reason HEV gt4 occasionally pops up in humans is uncertain, as previously HEV gt 4 was found almost exclusively in China and Japan (Kamar et al. 2014a).

As more accurate diagnostic tools have become available to assess current and distant infection, it is clear that many of the early epidemiological studies of locally acquired infection were flawed (Bendall et al. 2008, 2010). The reason for this is the very poor sensitivity of IgG
Epidemiology of HEV Genotype 3 and 4 Infections

anti-HEV assays for detecting infection in the distant past. As validated assays have become available that accurately assess distant infection, a clearer picture has started to emerge. A good example of this comes from studies in the Netherlands. In the early 1990s, the seroprevalence of HEV in the Netherlands was estimated to be $1.1 \%$ (Zaaijer et al. 1992). However, a more recent study using a sensitive IgG anti-HEV assay showed the seroprevalence to be $27 \%$ in 2011 (Slot et al. 2013), and when archived specimens were reexamined with the same assay the seroprevalence was found to be $46.6 \%$ in 1988 (Hogema et al. 2014).

The seroprevalence and incidence of locally acquired hepatitis E in Europe varies between and within countries and over time. Recent seroprevalence estimates for various European countries are shown in Table 1, and they range from $4.7 \%$ in Scotland (Cleland et al. 2013) to $29.5 \%$ in Germany (Wenzel et al. 2013). Likewise, incidence estimates vary considerably and, in general terms, countries with high seroprevalence have higher incidence estimates. A good example of this is the Netherlands where the seroprevalence is $27 \%$ and the incidence is $1.1 \%$ per person-year (Slot et al. 2013). The seroprevalence and incidence is also high in France $(22.4 \%$ and $1 \%$, respectively) (Mansuy et al. 2016). However, human infection with HEV is not uniformly geographically distributed in France. The region with the highest rates of past and present HEV infections in humans is Ariège in southwestern France with an incidence of $4.6 \%$ and seroprevalence of $82 \%$. In contrast, an area called Haute Loire, situated only $250 \mathrm{~km}$ to the north of Ariège, has an incidence of $0.4 \%$ and seroprevalence of $8 \%$. The reason for this 10 -fold difference in past and present circulating HEV in these two adjacent regions is unknown. High seroprevalence and incidence of HEV in humans has also been found in southeastern France, including Corsica. These areas have such a high incidence of human HEV infection that they can be considered hyperendemic (Mansuy et al. 2016).

During the last few decades, seroprevalence in England and Denmark has declined, with a large cohort of the population being infected 40 
H.R. Dalton and J. Izopet

or 50 years ago (Holm et al. 2015). However, in the last few years, many countries in Europe have seen very significant increases in laboratory-confirmed cases of HEV infection (Adlhoch et al. 2016), which in several countries is far more common than infection with hepatitis A virus (HAV) (Dalton et al. 2008b; Adlhoch et al. 2016). Much of this increase in reported human cases of HEV infection is likely the result of improved case ascertainment, as clinicians become more aware of HEV as a diagnostic possibility. However, there appears to have been a true increase in circulating $\mathrm{HEV}$ in humans in some countries, including the Netherlands (Zaaijer 2015), France (Mansuy et al. 2016), England (Hewitt et al. 2014), and Scotland (Thom et al. 2018).

In Scotland, the number of viremic blood donors has recently increased from 1:14,500 to 1:2481 and this has been accompanied by an increase in seroprevalence from $4.5 \%$ to $9.3 \%$ (Thom et al. 2018). Associated with this increase in incidence, the origin of human HEV infections appears to have changed in the United Kingdom. Previously, HEV strains documented in humans had close nucleotide sequence homology with HEV found in U.K. pigs (HEV gt3e), but such strains now bear very close sequence homology with HEV found in pigs in continental Europe (Ijaz et al. 2014). This implies there has been a recent significant change in the amount of HEV contamination of the human food chain originating in continental Europe. The precise origin of the increase in $\mathrm{HEV}$ infections in humans in the United Kingdom is uncertain. Case-control data suggest that the increase may relate to infected pork meat products from a single U.K. supermarket. This includes products that require cooking such as sausages, but also ready-to-eat items such as processed ham and pork pies (Said et al. 2017).

Recently, concern has been raised about the virological safety of porcine blood products used in both human and animal food. Pig blood is taken at the time of slaughter and made into various products in liquid or powder forms, including whole blood, plasma, hemoglobin, and fibrinogen. A study from the Netherlands has shown that these products contain HEV RNA
(Boxman et al. 2017). This is of considerable concern, as such products are used in many food products in the human food chain as meat "fillers" and "glues," including in readyto-eat items. In addition, pig blood products are increasingly marketed in Europe as growth promoters in animal (including pig) feed, following a European Union ban on antibiotics as growth promotors in animal feed (see www. europa.eu/rapid/press-release_IP-05-1687_en. htm). By industry estimates, 250 million pigs were given feed containing pig blood products in 2010 (see www.thepigsite.com/articles/3243/ fifth-quarter-value-of-pigs-blood). The importation to Europe of similar pig blood products from China is a possible explanation for occasional cases of HEV gt4 infection in humans in Europe. However, there are a number of questions that remain unanswered regarding such use of pig blood products, not the least of which is the issue of whether the HEV they contain is infectious to humans. This requires urgent investigation.

In recent years, it has become apparent that there are "hot spots" of HEV infection in Europe. This includes southwest France where the incidence of infection is 3\%-4\% (Mansuy et al. 2016); the Netherlands, where one of 600 blood donors was viremic in 2014 (Zaaijer 2015); Scotland, where one in 2481 donors was viremic in 2016-2017 (Thom et al. 2018); the Czech Republic, with 400 laboratory-confirmed infections in 2015 (Adlhoch et al. 2016); Abruzzo, central Italy, where the seroprevalence is $49 \%$ (Lucarelli et al. 2016); and western/central Poland, where the seroprevalence is 50\% (Bura et al. 2017) and one of 1033 donors viremic (Gdowska et al. 2016). There may well be other areas, as yet unidentified, with high levels of circulating virus.

\section{North America}

The epidemiology of HEV in North America is detailed elsewhere (see Hofmeister et al. 2018). However, two points deserve a brief mention. The epidemiology of HEV gt 3 and gt 4 is poorly understood in this geographical context. One important reason for this is the lack of human 
diagnostics approved by the U.S. Food and Drug Administration (FDA). This almost certainly has hampered our understanding of the epidemiology of zoonotic HEV on the continent. It also needs to be recognized that the continent of North America is vast. Data from Europe shows very considerable differences in circulating zoonotic HEV within small, discrete, and fairly adjacent areas. Thus, when additional epidemiological data do emerge from North America, this needs to be borne in mind.

\section{Latin America}

There have been quite a few epidemiological studies from South America in recent years. Collectively, these data show that the seroprevalence is higher than was previously thought to be the case. In addition, HEV gt 3 has been found in local pig populations and humans. HEV gt1 infection is very uncommon (Passos-Castilho et al. 2015; de Oliveira-Filho et al. 2017). The epidemiology of HEV in Latin America appears to bear close similarity to that found in developed countries such as Europe. The reasons why this should be the case are uncertain.

\section{Africa}

HEV gt1 and gt 2 are known to be endemic in regions of sub-Saharan Africa (see Nelson et al. 2018). However, there is a paucity of data regarding HEV gt 3 and gt 4 in Africa, although HEV gt 3 has been found in pigs in various locations. A recent study from South Africa showed that HEV gt 3 is circulating in humans, and that consumption of pig meat was a risk factor for anti-HEV seropositivity (Madden et al. 2016).

\section{Pacific Region}

The anti-HEV seroprevalence in the Pacific Islands has been incompletely studied. The seroprevalence ranges from 2\% in Fiji, $8.8 \%$ in Kiribati, to $15.2 \%$ in Papua New Guinea (Halliday et al. 2014). In the latter location, seroprevalence did not map uniformly, and was higher in the Highland areas. This might be explained by zoo-
Epidemiology of HEV Genotype 3 and 4 Infections

notic exposure caused by the higher number of household pigs in this area. Cases of locally acquired HEV gt 3 have been shown in both New Zealand and Australia, and HEV gt3 found in local pig populations (Garkavenko et al. 2001; Dalton et al. 2007). In Sydney, Australia, there was a recent outbreak caused by HEV gt 3 centered on a restaurant, most likely from a common liver pate food source (Yapa et al. 2016). However, compared with Europe, the number of viremic donors in Australia is low (1:14799 [Shrestha et al. 2016a] to 1:7413 [Hoad et al. 2017]). Although there currently appears to be relatively small amounts of circulating zoonotic HEV in Australia and New Zealand in humans, both countries are importing increasing amounts of pork meat and products from Europe (R Madden, pers. comm.), and so the situation warrants continued review.

\section{Asia}

In Japan, HEV gt 3 and gt 4 cocirculate in pigs and deer with infections occurring in humans. The epidemiology of HEV is thus very similar to that seen in Europe. Very recent data show that recent human infections in Japan were caused by HEV gt3 subtype $\mathrm{f}$ (gt3f); molecular epidemiological studies suggested that these strains originated in Europe, presumably arriving via infected imported pork meat products (Nakano et al. 2017).

China was previously considered hyperendemic for HEV gt1, and was the site of the biggest outbreak in human history in the late 1980s, with $\sim 120,000$ cases. However, during recent years, HEV gt4 appears to be the predominant circulating genotype in humans, and is also found in local pig populations. The reason for the shift from HEV gt1 to gt4 is unknown, but seems most prominent in Eastern China (Kamar et al. 2012). It is plausible that this might be accounted for by the improved sanitary infrastructure, which has asserted a negative ecological pressure on HEV gt1. In China, acute HEV infection is more common than HAV infection (Ren et al. 2017).

In Thailand, HEV gt 3 has been found in pigs, in pork products in the human food chain 
H.R. Dalton and J. Izopet

(Intharasongkroh et al. 2017), and in $4.8 \%$ of 613 cases of acute hepatitis (Siripanyaphinyo et al. 2014). Consumption of pig organs has been found to be a risk factor for HEV exposure (Hinjoy et al. 2013). In addition, the seroprevalence is significantly higher in the predominantly Buddhist area of central Thailand (37.3\%) compared with the south of the country (8.9\%), which is mainly Muslim (Sa-nguanmoo et al. 2015). Taken together, these data indicate that in Thailand the epidemiology of HEV is predominantly zoonotic. In Nepal, there are frequent outbreaks of hepatitis E caused by gt1, but recent data show that anti-HEV IgM and IgG seropositivity are associated with pork consumption (Shrestha et al. 2016b). The issue of cocirculating genotypes in developing countries requires further study.

\section{PREVENTION OF HEV GENOTYPE 3 AND 4 INFECTIONS}

The importance of an HEV infection as a cause of acute hepatitis and extrahepatic manifestations in high-income countries has not yet been fully recognized. The recent availability of powerful virological tools has brought about a massive change in our understanding of HEV epidemiology, including zoonotic transmission, its endemic nature in many industrialized countries, and the risk of transfusion-transmitted infection. Improved surveillance systems for monitoring human health, animal reservoirs, and the environment are needed to prevent and control this infection. The surveillance strategies and algorithms used in Europe vary greatly (Adlhoch et al. 2016; Aspinall et al. 2017) and are nonexistent in many industrialized countries. The wider use of metagenomics and next-generation sequencing should help to better define the animal reservoir and the risk of waterborne transmission.

\section{Prevention of Foodborne and Waterborne Transmission}

HEV gt 3 and gt 4 are predominantly transmitted via undercooked foodstuffs. The key to preventing their transmission is the control of HEV spreading through the pig-meat-production network: improved farming methods and hygiene practices (Salines et al. 2017). It is also essential to monitor pig livers and pork products, including the pig blood products used in cooked-meat production (Boxman et al. 2017). Consumer information and education about adequate cooking will help minimize the risk of transmission via the food chain (Salines et al. 2017). The HEV in pork-liver-based food products can only be efficiently inactivated by cooking for at least $20 \mathrm{~min}$ to obtain an internal temperature of $71^{\circ} \mathrm{C}$ (Feagins et al. 2008; Barnaud et al. 2012).

The extent of waterborne transmission of $\mathrm{HEV}$ gt 3 and gt 4 in industrialized countries is probably underestimated. We may well need a new approach to the surveillance of this type of transmission, such as metagenomic sequencing to get a clearer picture of the worldwide virus burden and then decide how to improve water quality.

\section{Prevention of Iatrogenic and Transfusion- Transmitted Infection}

The prevalence of viremic blood donations in developed countries and the high proportion of blood recipients that are immunocompromised have prompted practitioners to define optimal measures for increasing blood safety. Inactivation of pathogens in blood components using amotosalen is not effective for $\mathrm{HEV}$ (Hauser et al. 2014; Loyrion et al. 2017) and treatment with riboflavin (vitamin B2) plus ultraviolet light had only a limited effect (Owada et al. 2014). Clearly, new strategies for screening blood donations are needed (Domanovic et al. 2017). All blood donations are now screened in three European countries: Ireland (since 2016), the United Kingdom, and the Netherlands (the latter two since 2017). Plasma donations intended for transfusion into patients at risk have been selectively screened in France since 2013. France, Germany, and Switzerland are now considering screening blood donations, while Greece, Italy, Spain, and Portugal are evaluating the process (Domanovic et al. 2017). Individual testing or mini-pool testing, as well as pool size 
Epidemiology of HEV Genotype 3 and 4 Infections

all influence the cost-effectiveness of routine screening using any of the available nucleic acid testing methods (Vollmer et al. 2016c; de Vos et al. 2017; Gallian et al. 2017).

\section{Plasma-Derived Products}

Although there has been interest in screening human plasma donations for the presence of HEV RNA, current European recommendations do not call for universal testing (European Medicines Agency 2016). HEV inactivation and/or removal studies have examined several steps in the process of manufacturing plasma derivatives (Farcet et al. 2016; Yunoki et al.
2016). They indicate that nanofiltration is effective while ethanol fractionation removes little $\mathrm{HEV}$. Low $\mathrm{pH}$ treatment is ineffective while inactivation by liquid heating (pasteurization) depends on process conditions.

\section{Hematopoietic Stem Cells}

HSC donors, including those with normal aminotransferase activities, should be screened for HEV by nucleic acid testing (Mallet et al. 2016b). Components screened for HEV should be given to potential allogeneic HSC recipients from 3 months before the date of planned HSC transplantation and continued for 6 months fol-

Table 2. Epidemiology of hepatitis E virus (HEV) genotype (gt)3 and gt4: Research questions

\begin{tabular}{|c|c|}
\hline Topic & Research question \\
\hline $\begin{array}{l}\text { Virological } \\
\text { considerations }\end{array}$ & $\begin{array}{l}\text { What are the best algorithms based on serologic/molecular tests for improving HEV } \\
\text { screening? } \\
\text { Will metagenomics sequencing of human, animal, food, and environmental } \\
\text { specimens be helpful for improving the knowledge of HEV transmission chains? } \\
\text { Will experimental systems, including cell and animal models, provide a better } \\
\text { understanding of host tropism and HEV pathogenesis? }\end{array}$ \\
\hline Animal reservoirs & $\begin{array}{l}\text { What other animals are reservoirs for HEV infection, and what implications do they } \\
\text { have for human health? } \\
\text { Are the viral dynamics and infectivity of HEV gt } 3 \text { and gt } 4 \text { similar in both animal } \\
\text { and human populations? } \\
\text { What factors predict viremia in pigs at the time of slaughter? } \\
\text { What is the importance of animal feed containing pig blood products as a growth } \\
\text { enhancer in predicting viremia in animals at the time of slaughter? }\end{array}$ \\
\hline $\begin{array}{l}\text { Sources and routes of } \\
\text { infection }\end{array}$ & $\begin{array}{l}\text { What is the relative importance of consumption of infected pork meat and } \\
\text { environmental contamination in the spread of zoonotic HEV? } \\
\text { Is the HEV RNA found in pig blood products used in the human food chain } \\
\text { infective? } \\
\text { What relative role does this play in human infection? } \\
\text { How does this vary by geographical location? } \\
\text { Should all blood donors be screened for HEV? }\end{array}$ \\
\hline $\begin{array}{l}\text { Geographical } \\
\text { considerations }\end{array}$ & $\begin{array}{l}\text { Where are the "hot spots" of animal and human HEV located? } \\
\text { How have these changed over time? } \\
\text { Why does the force of infection vary between countries? } \\
\text { Why does the force of infection vary within countries? } \\
\text { Why is there little HEV gt } 1 \text { in some developing countries (e.g., South America) } \\
\text { compared with zoonotic HEV? } \\
\text { Do zoonotic HEV and HEV gt1 cocirculate in all developing countries? } \\
\text { How important is zoonotic HEV in such circumstances? } \\
\text { In some countries, we have little or no data about zoonotic HEV (e.g., South Africa, } \\
\text { Russia, and a number of Eastern European countries). What is the epidemiology } \\
\text { of zoonotic HEV in these settings? }\end{array}$ \\
\hline
\end{tabular}


H.R. Dalton and J. Izopet

lowing HSC transplantation, or for as long as the patient is immunosuppressed.

\section{Vaccines}

Two HEV vaccines have been developed based on recombinant capsid protein-forming viruslike particles (see Shouval 2018). Both have shown efficacy, although further clinical development of a vaccine tested in Nepal has ceased (Shrestha et al. 2007). A vaccine developed in China elicits protective antibodies to all HEV genotypes; it provided protection against gt1 and gt 4 in a large, phase 3 clinical trial and has been licensed in China since 2012 (Zhu et al. 2010). This vaccine is $97 \%$ effective (threedose course) in preventing symptomatic acute hepatitis, and has also proved to be effective in long-term follow-up studies (Zhang et al. 2015). Modeling suggests that it could provide protection for up to 30 years after vaccination (Su et al. 2017). Strategies for using this vaccine outside China have not been defined yet for either human or pig populations.

\section{CONCLUDING REMARKS}

Following the introduction of robust serological and molecular tools, our understanding of the epidemiology of zoonotic HEV has improved considerably in recent years. Current thinking suggests that consumption of pork meat products is the key route of infection in humans, but it is certainly not the only one. The epidemiology of HEV gt 3 and gt 4 is complex, as there are several sources and routes of infection, and it is likely that these vary between and within countries and over time. Many questions remain unanswered regarding the epidemiology of HEV gt3 and gt4 (Table 2). Recently, the European Centre for Disease Prevention and Control has taken an active role in addressing the threat of zoonotic HEV to the human population in Europe, using a "one health" approach. This has culminated in the establishment of "HEVnet," which is based at the Dutch National Institute for Public Health and the Environment in the Netherlands. The objective is to develop a central repository for human and animal HEV se- quences, together with key anonymized clinical data from human cases. "HEVnet" is, therefore, likely to be a very important tool for the improved future understanding of the epidemiology of HEV, at least in Europe.

\section{REFERENCES}

* Reference is also in this collection.

Abravanel F, Sandres-Saune K, Lhomme S, Dubois M, Mansuy JM, Izopet J. 2012. Genotype 3 diversity and quantification of hepatitis E virus RNA. J Clin Microbiol 50: 897-902.

Abravanel F, Chapuy-Regaud S, Lhomme S, Dubois M, Peron JM, Alric L, Rostaing L, Kamar N, Izopet J. 2013. Performance of two commercial assays for detecting hepatitis E virus RNA in acute or chronic infections. J Clin Microbiol 51: 1913-1916.

Abravanel F, Lhomme S, Chapuy-Regaud S, Mansuy JM, Muscari F, Sallusto F, Rostaing L, Kamar N, Izopet J. 2014. Hepatitis E virus reinfections in solid-organ-transplant recipients can evolve into chronic infections. J Infect Dis 209: 1900-1906.

Abravanel F, Lhomme S, Chapuy-Regaud S, Peron JM, Alric L, Rostaing L, Kamar N, Izopet J. 2015. Performance of a new rapid test for detecting anti-hepatitis $\mathrm{E}$ virus immunoglobulin $\mathrm{M}$ in immunocompetent and immunocompromised patients. J Clin Virol 70: 101-104.

Abravanel F, Goutagny N, Perret C, Lhomme S, Vischi F, Aversenq A, Chapel A, Dehainault N, Piga N, DupretCarruel J, et al. 2017a. Evaluation of two VIDAS prototypes for detecting anti-HEV IgG. J Clin Virol 89: 46-50.

Abravanel F, Lhomme S, Fougere M, Saune K, Alvarez M, Peron JM, Delobel P, Izopet J. 2017b. HEV infection in French HIV-infected patients. J Infect 74: 310-313.

Adlhoch C, Avellon A, Baylis SA, Ciccaglione AR, Couturier E, de Sousa R, Epstein J, Ethelberg S, Faber M, Feher A, et al. 2016. Hepatitis E virus: Assessment of the epidemiological situation in humans in Europe, 2014/15. J Clin Virol 82: 9-16.

Amon JJ, Drobeniuc J, Bower WA, Magana JC, Escobedo MA, Williams IT, Bell BP, Armstrong GL. 2006. Locally acquired hepatitis E virus infection, El Paso, Texas. J Med Virol 78: 741-746.

Andersson MI, Hughes J, Gordon FH, Ijaz S, Donati M. 2008. Of pigs and pregnancy. Lancet 372: 1192.

Anty R, Ollier L, Peron JM, Nicand E, Cannavo I, Bongain A, Giordanengo V, Tran A. 2012. First case report of an acute genotype 3 hepatitis $\mathrm{E}$ infected pregnant woman living in South-Eastern France. J Clin Virol 54: 76-78.

Aspinall EJ, Couturier E, Faber M, Said B, Ijaz S, Tavoschi L, Takkinen J, Adlhoch C; Country experts. 2017. Hepatitis E virus infection in Europe: Surveillance and descriptive epidemiology of confirmed cases, 2005 to 2015. Euro Surveill 22: 30561

Avellon A, Morago L, Garcia-Galera del Carmen M, Munoz M, Echevarria JM. 2015. Comparative sensitivity of commercial tests for hepatitis E genotype 3 virus antibody detection. J Med Virol 87: 1934-1939. 
Balayan MS, Andjaparidze AG, Savinskaya SS, Ketiladze ES Braginsky DM, Savinov AP, Poleschuk VF. 1983. Evidence for a virus in non-A, non-B hepatitis transmitted via the fecal-oral route. Intervirology 20: 23-31.

Barnaud E, Rogee S, Garry P, Rose N, Pavio N. 2012. Thermal inactivation of infectious hepatitis E virus in experimentally contaminated food. Appl Environ Microbiol 78: 5153-5159.

Baylis SA, Hanschmann KM, Blumel J, Nubling CM, Group HEVCS. 2011. Standardization of hepatitis E virus (HEV) nucleic acid amplification technique-based assays: An initial study to evaluate a panel of HEV strains and investigate laboratory performance. J Clin Microbiol 49: 12341239.

Baylis SA, Gartner T, Nick S, Ovemyr J, Blumel J. 2012. Occurrence of hepatitis E virus RNA in plasma donations from Sweden, Germany and the United States. Vox Sang 103: 89-90.

Baylis SA, Blumel J, Mizusawa S, Matsubayashi K, Sakata H, Okada Y, Nubling CM, Hanschmann KM, Group HEVCS. 2013. World Health Organization International Standard to harmonize assays for detection of hepatitis E virus RNA. Emerg Infect Dis 19: 729-735.

Beale MA, Tettmar K, Szypulska R, Tedder RS, Ijaz S. 2011. Is there evidence of recent hepatitis $\mathrm{E}$ virus infection in English and North Welsh blood donors? Vox Sang 100: 340-342.

Behrendt P, Bremer B, Todt D, Brown RJ, Heim A, Manns MP, Steinmann E, Wedemeyer H. 2016. Hepatitis E virus (HEV) ORF2 antigen levels differentiate between acute and chronic HEV infection. J Infect Dis 214: 361-368.

Bendall R, Ellis V, Ijaz S, Thurairajah P, Dalton HR. 2008. Serological response to hepatitis $\mathrm{E}$ virus genotype 3 infection: IgG quantitation, avidity, and IgM response. J Med Virol 80: 95-101.

Bendall R, Ellis V, Ijaz S, Ali R, Dalton H. 2010. A comparison of two commercially available anti-HEV IgG kits and a re-evaluation of anti-HEV IgG seroprevalence data in developed countries. J Med Virol 82: 799-805.

Bisseux M, Colombet J, Mirand A, Roque Afonso AM, Abravanel F, Izopet J, Archimbaud C, Peigue-Lafeuille H, Debroas D, Bailly J, et al. 2018. Monitoring human enteric viruses in wastewater and relevance to infections encountered in the clinical setting: Results of a one-year experiment in Central France. Euro Surveill (in press).

Bouamra Y, Gerolami R, Arzouni JP, Grimaud JC, Lafforgue P, Nelli M, Tivoli N, Ferretti A, Motte A, Colson P. 2014 Emergence of autochthonous infections with hepatitis $\mathrm{E}$ virus of genotype 4 in Europe. Intervirology 57: 43-48.

Boxall E, Herborn A, Kochethu G, Pratt G, Adams D, Ijaz S, Teo CG. 2006. Transfusion-transmitted hepatitis E in a "nonhyperendemic" country. Transfus Med 16: 79-83.

Boxman ILA, Jansen CCC, Hagele G, Zwartkruis-Nahuis A, Cremer J, Vennema H, Tijsma ASL. 2017. Porcine blood used as ingredient in meat productions may serve as a vehicle for hepatitis E virus transmission. Int J Food Microbiol 257: 225-231.

Bura M, Lagiedo M, Michalak M, Sikora J, Mozer-Lisewska I. 2017. Hepatitis E virus IgG seroprevalence in HIV patients and blood donors, west-central Poland. Int I Infect Dis 61: 20-22.
Epidemiology of HEV Genotype 3 and 4 Infections

Cattoir L, Van Hoecke F, Van Maerken T, Nys E, Ryckaert I, De Boulle M, Geerts A, Verhelst X, Colle I, Hutse V, et al. 2017. Hepatitis E virus serology and PCR: Does the methodology matter? Arch Virol 162: 2625-2632.

Chapuy-Regaud S, Dubois M, Plisson-Chastang C, Bonnefois T, Lhomme S, Bertrand-Michel J, You B, Simoneau S, Gleizes PE, Flan B, et al. 2017. Characterization of the lipid envelope of exosome encapsulated HEV particles protected from the immune response. Biochimie 141: 70-79.

Chen YJ, Cao NX, Xie RH, Ding CX, Chen EF, Zhu HP, Sun JM, Shang XP, Wang XX, Miao ZP. 2016. Epidemiological investigation of a tap water-mediated hepatitis $\mathrm{E}$ virus genotype 4 outbreak in Zhejiang Province, China. Epidemiol Infect doi: 10.1017/S0950268816001898.

Cleland A, Smith L, Crossan C, Blatchford O, Dalton HR, Scobie L, Petrik J. 2013. Hepatitis E virus in Scottish blood donors. Vox Sang 105: 283-289.

Coilly A, Haim-Boukobza S, Roche B, Antonini TM, Pause A, Mokhtari C, Becq A, Farahmand H, Hauser L, DuclosVallee JC, et al. 2013. Posttransplantation hepatitis E: Transfusion-transmitted hepatitis rising from the ashes. Transplantation 96: e4-e6.

Colson P, Kaba M, Bernit E, Motte A, Tamalet C. 2007. Hepatitis $\mathrm{E}$ associated with surgical training on pigs. Lancet 370: 935 .

Colson P, Borentain P, Queyriaux B, Kaba M, Moal V, Gallian P, Heyries L, Raoult D, Gerolami R. 2010. Pig liver sausage as a source of hepatitis $\mathrm{E}$ virus transmission to humans. J Infect Dis 202: 825-834.

Dalton HR, Fellows HJ, Gane EJ, Wong P, Gerred S, Schroeder B, Croxson MC, Garkavenko O. 2007. Hepatitis E in New Zealand. J Gastroenterol Hepatol 22: 12361240.

Dalton HR, Bendall R, Ijaz S, Banks M. 2008a. Hepatitis E: An emerging infection in developed countries. Lancet Infect Dis 8: 698-709.

Dalton HR, Stableforth W, Hazeldine S, Thurairajah P, Ramnarace R, Warshow U, Ijaz S, Ellis V, Bendall R. 2008b. Autochthonous hepatitis E in Southwest England: A comparison with hepatitis A. Eur J Clin Microbiol Infect Dis 27: $579-585$.

Debing Y, Gisa A, Dallmeier K, Pischke S, Bremer B, Manns M, Wedemeyer H, Suneetha PV, Neyts J. 2014. A mutation in the hepatitis $\mathrm{E}$ virus RNA polymerase promotes its replication and associates with ribavirin treatment failure in organ transplant recipients. Gastroenterology 147: 1008-1011.e1007; quiz e15-6.

Debing Y, Ramiere C, Dallmeier K, Piorkowski G, Trabaud MA, Lebosse F, Scholtes C, Roche M, Legras-Lachuer C, de Lamballerie X, et al. 2016. Hepatitis E virus mutations associated with ribavirin treatment failure result in altered viral fitness and ribavirin sensitivity. J Hepatol 65: 499508.

de Oliveira-Filho EF, Lopes KG, Cunha DS, Silva VS, Barbosa CN, Brandespim DF, Junior JW, Bertani GR, Gil LH. 2017. Risk analysis and occurrence of hepatitis $E$ virus (HEV) in domestic swine in northeast Brazil. Food Environ Virol 9: 256-259.

de Vos AS, Janssen MP, Zaaijer HL, Hogema BM. 2017. Cost-effectiveness of the screening of blood donations 
H.R. Dalton and J. Izopet

for hepatitis E virus in the Netherlands. Transfusion $\mathbf{5 7}$ 258-266.

Doceul V, Bagdassarian E, Demange A, Pavio N. 2016. Zoonotic hepatitis E virus: Classification, animal reservoirs and transmission routes. Viruses 8: E270.

Domanovic D, Tedder R, Blumel J, Zaaijer H, Gallian P, Niederhauser C, Sauleda Oliveras S, O’Riordan J, Boland F, Harritshoj L, et al. 2017. Hepatitis E and blood donation safety in selected European countries: A shift to screening? Euro Surveill 22: 30514

Drobeniuc J, Meng J, Reuter G, Greene-Montfort T, Khudyakova N, Dimitrova Z, Kamili S, Teo CG. 2010. Serologic assays specific to immunoglobulin $M$ antibodies against hepatitis E virus: Pangenotypic evaluation of performances. Clin Infect Dis 51: e24-e27.

European Medicines Agency. 2016. Reflection paper on viral safety of plasma-derived medicinal products with respect to hepatitis E virus. www.ema.europa.eu/docs/en_GB/ document_library/Scientific_guideline/2016/06/WC5002 09354.pdf.

Farcet MR, Lackner C, Antoine G, Rabel PO, Wieser A, Flicker A, Unger U, Modrof J, Kreil TR. 2016. Hepatitis $\mathrm{E}$ virus and the safety of plasma products: Investigations into the reduction capacity of manufacturing processes. Transfusion 56: 383-391.

Feagins AR, Opriessnig T, Guenette DK, Halbur PG, Meng XJ. 2008. Inactivation of infectious hepatitis $E$ virus present in commercial pig livers sold in local grocery stores in the United States. Int J Food Microbiol 123: 32-37.

Feng Z, Hirai-Yuki A, McKnight KL, Lemon SM. 2014. Naked viruses that aren't always naked: Quasi-enveloped agents of acute hepatitis. Annu Rev Virol 1: 539-560.

Fischer C, Hofmann M, Danzer M, Hofer K, Kaar J, Gabriel C. 2015. Seroprevalence and incidence of hepatitis $E$ in blood donors in upper Austria. PLoS ONE 10: e0119576.

Frange P, Roque-Afonso AM, Neven B, Moshous D, Touzot F, Cavazzana M, Fischer A, Leruez-Ville M, Blanche S. 2015. Hepatitis E virus in hematopoietic stem cell donors: Towards a systematic HEV screening of donors? J Infect 71: $141-144$.

Gallian P, Lhomme S, Piquet Y, Saune K, Abravanel F, Assal A, Tiberghien P, Izopet J. 2014. Hepatitis E virus infections in blood donors, France. Emerg Infect Dis 20: 19141917.

Gallian P, Couchouron A, Dupont I, Fabra C, Piquet Y, Djoudi R, Assal A, Tiberghien P. 2017. Comparison of hepatitis $\mathrm{E}$ virus nucleic acid test screening platforms and RNA prevalence in French blood donors. Transfusion 57: 223-224.

Garkavenko O, Obriadina A, Meng J, Anderson DA, Benard HJ, Schroeder BA, Khudyakov YE, Fields HA, Croxson MC. 2001. Detection and characterisation of swine hepatitis E virus in New Zealand. J Med Virol 65: 525-529.

Gdowska J, Sulkowska E, Grabarczyk P, Galik R, Piotrowski D, Wasiela M. 2016. Efficiency of transcription-mediated amplification (TMA) in detecting hepatitis $\mathrm{E}$ in blood donors from regional centre of transfusion medicine and blood bank in Warsaw-A new risk in transfusion. International Society of Blood Transfusion. Vox Sang 111: P-264.
Geng Y, Zhao C, Huang W, Harrison TJ, Zhang H, Geng K, Wang Y. 2016. Detection and assessment of infectivity of hepatitis E virus in urine. J Hepatol 64: 37-43.

Guillois Y, Abravanel F, Miura T, Pavio N, Vaillant V, Lhomme S, Le Guyader FS, Rose N, Le Saux JC, King LA, et al. 2016. High proportion of asymptomatic infections in an outbreak of hepatitis $\mathrm{E}$ associated with a spitroasted piglet, France, 2013. Clin Infect Dis 62: 351-357.

Guo QS, Yan Q, Xiong JH, Ge SX, Shih JW, Ng MH, Zhang J, Xia NS. 2010. Prevalence of hepatitis E virus in Chinese blood donors. J Clin Microbiol 48: 317-318.

Haim-Boukobza S, Ferey MP, Vetillard AL, Jeblaoui A, Pelissier E, Pelletier G, Teillet L, Roque-Afonso AM. 2012. Transfusion-transmitted hepatitis $\mathrm{E}$ in a misleading context of autoimmunity and drug-induced toxicity. $J$ Hepatol 57: 1374-1378.

Halliday JS, Harrison GL, Brown A, Hunter JG, Bendall R, Penny D, Toatu T, Abdad MY, Klenerman P, Barnes E, et al. 2014. Hepatitis E virus infection, Papua New Guinea, Fiji, and Kiribati, 2003-2005. Emerg Infect Dis 20: 1057-1058.

Harritshoj LH, Holm DK, Saekmose SG, Jensen BA, Hogema BM, Fischer TK, Midgley SE, Krog JS, Erikstrup C, Ullum H. 2016. Low transfusion transmission of hepatitis $\mathrm{E}$ among 25,637 single-donation, nucleic acid-tested blood donors. Transfusion 56: 2225-2232.

Hartl J, Otto B, Madden RG, Webb G, Woolson KL, Kriston L, Vettorazzi E, Lohse AW, Dalton HR, Pischke S. 2016a. Hepatitis E seroprevalence in Europe: A meta-analysis. Viruses 8: E211.

Hartl J, Wehmeyer MH, Pischke S. 2016b. Acute hepatitis E: Two sides of the same coin. Viruses 8: 299.

Hauser L, Roque-Afonso AM, Beyloune A, Simonet M, Deau Fischer B, Burin des Roziers N, Mallet V, Tiberghien P, Bierling P. 2014. Hepatitis E transmission by transfusion of Intercept blood system-treated plasma. Blood 123: 796-797.

Hewitt PE, Ijaz S, Brailsford SR, Brett R, Dicks S, Haywood B, Kennedy IT, Kitchen A, Patel P, Poh J, et al. 2014. Hepatitis $\mathrm{E}$ virus in blood components: A prevalence and transmission study in southeast England. Lancet 384: 1766-1773.

Hinjoy S, Nelson KE, Gibbons RV, Jarman RG, Mongkolsirichaikul D, Smithsuwan P, Fernandez S, Labrique AB, Patchanee P. 2013. A cross-sectional study of hepatitis E virus infection in healthy people directly exposed and unexposed to pigs in a rural community in northern Thailand. Zoonoses Public Health 60: 555-562.

Hoad VC, Seed CR, Fryk JJ, Harley R, Flower RLP, Hogema BM, Kiely P, Faddy HM. 2017. Hepatitis E virus RNA in Australian blood donors: Prevalence and risk assessment. Vox Sang 112: 614-621.

* Hofmeister MG, Foster MA, Teshale EH. 2018. Epidemiology and transmission of hepatitis A virus and hepatitis $\mathrm{E}$ virus infections in the United States. Cold Spring Harb Perspect Med doi: 10.1101/cshperspect.a033431.

Hogema BM, Molier M, Slot E, Zaaijer HL. 2014. Past and present of hepatitis E in the Netherlands. Transfusion 54: 3092-3096.

Holm DK, Moessner BK, Engle RE, Zaaijer HL, Georgsen J, Purcell RH, Christensen PB. 2015. Declining prevalence 
of hepatitis E antibodies among Danish blood donors. Transfusion 55: 1662-1667.

Hunter JG, Madden RG, Stone AM, Osborne N, Wheeler B, Vine L, Dickson A, Barlow M, Lewis J, Bendall RP, et al. 2016. Coastal clustering of HEV; Cornwall, UK. Eur J Gastroenterol Hepatol 28: 323-327.

Huzly D, Umhau M, Bettinger D, Cathomen T, Emmerich F, Hasselblatt P, Hengel H, Herzog R, Kappert O, Maassen S, et al. 2014. Transfusion-transmitted hepatitis E in Germany, 2013. Euro Surveill 19: 20812.

Ijaz S, Szypulska R, Tettmar KI, Kitchen A, Tedder RS. 2012. Detection of hepatitis E virus RNA in plasma mini-pools from blood donors in England. Vox Sang 102: 272.

Ijaz S, Said B, Boxall E, Smit E, Morgan D, Tedder RS. 2014. Indigenous hepatitis E in England and Wales from 2003 to 2012: Evidence of an emerging novel phylotype of viruses. J Infect Dis 209: 1212-1218.

Intharasongkroh D, Sa-Nguanmoo P, Tuanthap S, Thongmee T, Duang-In A, Klinfueng S, Chansaenroj J, Vongpunsawad S, Theamboonlers A, Payungporn S, et al. 2017. Hepatitis $\mathrm{E}$ virus in pork and variety meats sold in fresh markets. Food Environ Virol 9: 45-53.

Kamar N, Rostaing L, Abravanel F, Garrouste C, Lhomme S, Esposito L, Basse G, Cointault O, Ribes D, Nogier MB, et al. 2010. Ribavirin therapy inhibits viral replication on patients with chronic hepatitis e virus infection. Gastroenterology 139: 1612-1618.

Kamar N, Bendall R, Legrand-Abravanel F, Xia NS, Ijaz S, Izopet J, Dalton HR. 2012. Hepatitis E. Lancet 379: $2477-$ 2488.

Kamar N, Rostaing L, Legrand-Abravanel F, Izopet J. 2013. How should hepatitis E virus infection be defined in organ-transplant recipients? Am J Transplant 13: 19351936.

Kamar N, Dalton HR, Abravanel F, Izopet J. 2014a. Hepatitis E virus infection. Clin Microbiol Rev 27: 116-138.

Kamar N, Mallet V, Izopet J. 2014b. Ribavirin for chronic hepatitis E virus infection. N Engl J Med 370: 2447-2448.

Kasorndorkbua C, Opriessnig T, Huang FF, Guenette DK, Thomas PJ, Meng XJ, Halbur PG. 2005. Infectious swine hepatitis $\mathrm{E}$ virus is present in pig manure storage facilities on United States farms, but evidence of water contamination is lacking. Appl Environ Microbiol 71: 7831-7837.

* Kenney SP, Meng X-J. 2018. Hepatitis E virus genome structure and replication strategy. Cold Spring Harb Perspect Med doi: 10.1101/cshperspect.a031724.

Koenecke C, Pischke S, Beutel G, Ritter U, Ganser A, Wedemeyer H, Eder M. 2014. Hepatitis E virus infection in a hematopoietic stem cell donor. Bone Marrow Transplant 49: $159-160$

Lan X, Yang B, Li BY, Yin XP, Li XR, Liu JX. 2009. Reverse transcription-loop-mediated isothermal amplification assay for rapid detection of hepatitis E virus. J Clin Microbiol 47: 2304-2306.

La Rosa G, Pourshaban M, Iaconelli M, Vennarucci VS, Muscillo M. 2010. Molecular detection of hepatitis E virus in sewage samples. Appl Environ Microbiol 76: 58705873.

Lee GH, Tan BH, Teo EC, Lim SG, Dan YY, Wee A, Aw PP, Zhu Y, Hibberd ML, Tan CK, et al. 2016. Chronic infection with camelid hepatitis $\mathrm{E}$ virus in a liver transplant
Epidemiology of HEV Genotype 3 and 4 Infections

recipient who regularly consumes camel meat and milk. Gastroenterology 150: 355-357 e353.

Legrand-Abravanel F, Mansuy JM, Dubois M, Kamar N, Peron JM, Rostaing L, Izopet J. 2009a. Hepatitis E virus genotype 3 diversity, France. Emerg Infect Dis 15: 110114.

Legrand-Abravanel F, Thevenet I, Mansuy JM, Saune K, Vischi F, Peron JM, Kamar N, Rostaing L, Izopet J. 2009b. Good performance of immunoglobulin M assays in diagnosing genotype 3 hepatitis E virus infections. Clin Vaccine Immunol 16: 772-774.

Lewis HC, Boisson S, Ijaz S, Hewitt K, Ngui SL, Boxall E, Teo CG, Morgan D. 2008. Hepatitis E in England and Wales. Emerg Infect Dis 14: 165-167.

Lhomme S, Kamar N, Nicot F, Ducos J, Bismuth M, Garrigue V, Petitjean-Lecherbonnier J, Ollivier I, Alessandri-Gradt E, Goria O, et al. 2015. Mutation in the hepatitis E virus polymerase and outcome of ribavirin therapy. Antimicrob Agents Chemother 60: 1608-1614.

Lhomme S, Bardiaux L, Abravanel F, Gallian P, Kamar N, Izopet J. 2017. Hepatitis E virus infection in solid organ transplant recipients, France. Emerg Infect Dis 23: 353356.

Li TC, Chijiwa K, Sera N, Ishibashi T, Etoh Y, Shinohara Y, Kurata Y, Ishida M, Sakamoto S, Takeda N, et al. 2005. Hepatitis E virus transmission from wild boar meat. Emerg Infect Dis 11: 1958-1960.

Loyrion E, Trouve-Buisson T, Pouzol P, Larrat S, Decaens T, Payen JF. 2017. Hepatitis E virus infection after platelet transfusion in an immunocompetent trauma patient. Emerg Infect Dis 23: 146-147.

Lucarelli C, Spada E, Taliani G, Chionne P, Madonna E, Marcantonio C, Pezzotti P, Bruni R, La Rosa G, Pisani $\mathrm{G}$, et al. 2016. High prevalence of anti-hepatitis $\mathrm{E}$ virus antibodies among blood donors in central Italy, February to March 2014. Euro Surveill 21: 30299.

Madden RG, Wallace S, Sonderup M, Korsman S, Chivese T, Gavine B, Edem A, Govender R, English N, Kaiyamo C, et al. 2016. Hepatitis E virus: Western Cape, South Africa. World J Gastroenterol 22: 9853-9859.

Mallet V, Sberro-Soussan R, Vallet-Pichard A, Roque-Afonso AM, Pol S. 2016a. Transmission of hepatitis E virus by plasma exchange: A case report. Ann Intern Med 164: 851-852.

Mallet V, van Bommel F, Doerig C, Pischke S, Hermine O, Locasciulli A, Cordonnier C, Berg T, Moradpour D, Wedemeyer H, et al. 2016b. Management of viral hepatitis in patients with haematological malignancy and in patients undergoing haemopoietic stem cell transplantation: Recommendations of the 5th European Conference on Infections in Leukaemia (ECIL-5). Lancet Infect Dis 16: 606617.

Mansuy JM, Peron JM, Abravanel F, Poirson H, Dubois M, Miedouge M, Vischi F, Alric L, Vinel JP, Izopet J. 2004. Hepatitis E in the south west of France in individuals who have never visited an endemic area. J Med Virol 74: 419424.

Mansuy JM, Huynh A, Abravanel F, Recher C, Peron JM, Izopet J. 2009. Molecular evidence of patient-to-patient transmission of hepatitis $\mathrm{E}$ virus in a hematology ward. Clin Infect Dis 48: 373-374. 
H.R. Dalton and J. Izopet

Mansuy JM, Bendall R, Legrand-Abravanel F, Saune K, Miedouge M, Ellis V, Rech H, Destruel F, Kamar N, Dalton HR, et al. 2011. Hepatitis E virus antibodies in blood donors, France. Emerg Infect Dis 17: 2309-2312.

Mansuy JM, Saune K, Rech H, Abravanel F, Mengelle C, Lhomme S, Destruel F, Kamar N, Izopet J. 2015. Seroprevalence in blood donors reveals widespread, multisource exposure to hepatitis E virus, southern France, October 2011. Euro Surveill 20: 27-34.

Mansuy JM, Gallian P, Dimeglio C, Saune K, Arnaud C, Pelletier B, Morel P, Legrand D, Tiberghien P, Izopet J. 2016. A nationwide survey of hepatitis E viral infection in French blood donors. Hepatology 63: 1145-1154.

Matsubayashi K, Nagaoka Y, Sakata H, Sato S, Fukai K, Kato T, Takahashi K, Mishiro S, Imai M, Takeda N, et al. 2004. Transfusion-transmitted hepatitis E caused by apparently indigenous hepatitis E virus strain in Hokkaido, Japan. Transfusion 44: 934-940.

Matsubayashi K, Kang JH, Sakata H, Takahashi K, Shindo M, Kato M, Sato S, Kato T, Nishimori H, Tsuji K, et al 2008. A case of transfusion-transmitted hepatitis E caused by blood from a donor infected with hepatitis $\mathrm{E}$ virus via zoonotic food-borne route. Transfusion 48: 1368-1375.

McCreary C, Martelli F, Grierson S, Ostanello F, Nevel A, Banks M. 2008. Excretion of hepatitis E virus by pigs of different ages and its presence in slurry stores in the United Kingdom. Vet Rec 163: 261-265.

Meng XJ, Purcell RH, Halbur PG, Lehman JR, Webb DM, Tsareva TS, Haynes JS, Thacker BJ, Emerson SU. 1997. A novel virus in swine is closely related to the human hepatitis E virus. Proc Natl Acad Sci 94: 9860-9865.

Meng XJ, Halbur PG, Shapiro MS, Govindarajan S, Bruna JD, Mushahwar IK, Purcell RH, Emerson SU. 1998. Genetic and experimental evidence for cross-species infection by swine hepatitis E virus. J Virol 72: 9714-9721.

Minagi T, Okamoto H, Ikegawa M, Ideno S, Takahashi K, Sakai K, Hagiwara K, Yunoki M, Wakisaka A. 2016. Hepatitis $\mathrm{E}$ virus in donor plasma collected in Japan. Vox Sang 111: $242-246$.

Miura T, Lhomme S, Le Saux JC, Le Mehaute P, Guillois Y, Couturier E, Izopet J, Abranavel F, Le Guyader FS. 2016. Detection of hepatitis E virus in sewage after an outbreak on a French island. Food Environ Virol 8: 194-199.

Nakano T, Takahashi M, Takahashi K, Nagashima S, Suzuki Y, Nishigaki Y, Tomita E, Okano H, Oya Y, Shiraki K, et al. 2017. Hepatitis E virus subtype 3 f strains isolated from Japanese hepatitis patients with no history of travel to endemic areas-The origin analyzed by molecular evolution. Virology 513: 146-152.

* Nelson KE, Labrique AB, Kmush BL. 2018. Epidemiology of genotype 1 and 2 hepatitis E virus infections. Cold Spring Harb Perspect Med doi: 10.1101/cshperspect.a031732.

Nicot F, Cazabat M, Lhomme S, Marion O, Saune K, Chiabrando J, Dubois M, Kamar N, Abravanel F, Izopet J. 2016. Quantification of HEV RNA by droplet digital PCR. Viruses 8: E233.

Norder H, Karlsson M, Mellgren A, Konar J, Sandberg E, Lasson A, Castedal M, Magnius L, Lagging M. 2016. Diagnostic performance of five assays for anti-hepatitis $\mathrm{E}$ virus IgG and IgM in a large cohort study. J Clin Microbiol 54: $549-555$
O’Donghaile D, O'Flaherty N, Field S. 2017. Early hepatitis E infection in an unrelated hematopoietic progenitor stem cell donor. Bone Marrow Transplant 52: 1471-1472.

O'Riordan J, Boland F, Williams P, Donnellan J, Hogema BM, Ijaz S, Murphy WG. 2016. Hepatitis E virus infection in the Irish blood donor population. Transfusion 56: 2868-2876.

Owada T, Kaneko M, Matsumoto C, Sobata R, Igarashi M, Suzuki K, Matsubayashi K, Mio K, Uchida S, Satake M, et al. 2014. Establishment of culture systems for genotypes 3 and 4 hepatitis E virus (HEV) obtained from human blood and application of HEV inactivation using a pathogen reduction technology system. Transfusion 54: 28202827.

Pas SD, Streefkerk RH, Pronk M, de Man RA, Beersma MF, Osterhaus AD, van der Eijk AA. 2013. Diagnostic performance of selected commercial HEV IgM and IgG ELISAs for immunocompromised and immunocompetent patients. J Clin Virol 58: 629-634.

Passos-Castilho AM, de Sena A, Reinaldo MR, Granato CF. 2015. Hepatitis E virus infection in Brazil: Results of laboratory-based surveillance from 1998 to 2013. Rev Soc Bras Med Trop 48: 468-470.

Petrik J, Lozano M, Seed CR, Faddy HM, Keller AJ, Prado Scuracchio PS, Wendel S, Andonov A, Fearon M, Delage G, et al. 2016. Hepatitis E. Vox Sang 110: 93-130.

Pisanic N, Rahman A, Saha SK, Labrique AB, Nelson KE, Granger DA, Granger SW, Detrick B, Heaney CD. 2017. Development of an oral fluid immunoassay to assess past and recent hepatitis E virus (HEV) infection. J Immunol Methods 448: 1-8.

Pourbaix A, Ouali N, Soussan P, Roque Afonso AM, Peraldi MN, Rondeau E, Peltier J. 2017. Evidence of hepatitis E virus transmission by renal graft. Transpl Infect Dis 19: e12624.

Ren X, Wu P, Wang L, Geng M, Zeng L, Zhang J, Xia N, Lai S, Dalton HR, Cowling BJ, et al. 2017. Changing epidemiology of hepatitis A and hepatitis $\mathrm{E}$ viruses in China, 1990-2014. Emerg Infect Dis 23: 276-279.

Renou C, Cadranel JF, Bourliere M, Halfon P, Ouzan D, Rifflet H, Carenco P, Harafa A, Bertrand JJ, Boutrouille A, et al. 2007. Possible zoonotic transmission of hepatitis E from pet pig to its owner. Emerg Infect Dis 13: 10941096.

Renou C, Roque-Afonso AM, Pavio N. 2014. Foodborne transmission of hepatitis $\mathrm{E}$ virus from raw pork liver sausage, France. Emerg Infect Dis 20: 1945-1947.

Reyes GR, Purdy MA, Kim JP, Luk KC, Young LM, Fry KE, Bradley DW. 1990. Isolation of a cDNA from the virus responsible for enterically transmitted non-A, non-B hepatitis. Science 247: 1335-1339.

Riveiro-Barciela M, Minguez B, Girones R, Rodriguez-Frias F, Quer J, Buti M. 2015. Phylogenetic demonstration of hepatitis $\mathrm{E}$ infection transmitted by pork meat ingestion. $J$ Clin Gastroenterol 49: 165-168.

Riveiro-Barciela M, Sauleda S, Quer J, Salvador F, Gregori J, Piron M, Rodriguez-Frias F, Buti M. 2017. Red blood cell transfusion-transmitted acute hepatitis $\mathrm{E}$ in an immunocompetent subject in Europe: A case report. Transfusion 57: 244-247. 
Epidemiology of HEV Genotype 3 and 4 Infections

Said B, Ijaz S, Kafatos G, Booth L, Thomas HL, Walsh A, Ramsay M, Morgan D, Hepatitis EIIT. 2009. Hepatitis E outbreak on cruise ship. Emerg Infect Dis 15: 1738-1744.

Said B, Usdin M, Warburton F, Ijaz S, Tedder RS, Morgan D. 2017. Pork products associated with human infection caused by an emerging phylotype of hepatitis $\mathrm{E}$ virus in England and Wales. Epidemiol Infect 145: 2417-2423.

Salines M, Andraud M, Rose N. 2017. From the epidemiology of hepatitis $\mathrm{E}$ virus (HEV) within the swine reservoir to public health risk mitigation strategies: A comprehensive review. Vet Res 48: 31.

Sa-nguanmoo P, Posuwan N, Vichaiwattana P, Wutthiratkowit N, Owatanapanich S, Wasitthankasem R, Thongmee T, Poovorawan K, Theamboonlers A, Vongpunsawad S, et al. 2015. Swine is a possible source of hepatitis $E$ virus infection by comparative study of hepatitis A and E seroprevalence in Thailand. PLOS ONE 10: e0126184.

Satake M, Matsubayashi K, Hoshi Y, Taira R, Furui Y, Kokudo N, Akamatsu N, Yoshizumi T, Ohkohchi N, Okamoto $\mathrm{H}$, et al. 2017. Unique clinical courses of transfusion-transmitted hepatitis $\mathrm{E}$ in patients with immunosuppression. Transfusion 57: 280-288.

Sauleda S, Ong E, Bes M, Janssen A, Cory R, Babizki M, Shin T, Lindquist A, Hoang A, Vang L, et al. 2015. Seroprevalence of hepatitis E virus (HEV) and detection of HEV RNA with a transcription-mediated amplification assay in blood donors from Catalonia (Spain). Transfusion 55: 972-979.

Schemmerer M, Rauh C, Jilg W, Wenzel JJ. 2017. Time course of hepatitis E-specific antibodies in adults. J Viral Hepat 24: 75-79.

Schlosser B, Stein A, Neuhaus R, Pahl S, Ramez B, Kruger DH, Berg T, Hofmann J. 2012. Liver transplant from a donor with occult HEV infection induced chronic hepatitis and cirrhosis in the recipient. J Hepatol 56: 500-502.

Schnegg A, Burgisser P, Andre C, Kenfak-Foguena A, Canellini G, Moradpour D, Abravanel F, Izopet J, Cavassini M, Darling KE. 2013. An analysis of the benefit of using HEV genotype 3 antigens in detecting anti-HEV IgG in a European population. PLoS ONE 8: e62980.

Servant-Delmas A, Abravanel F, Lefrere JJ, Lionnet F, Hamon C, Izopet J, Laperche S. 2016. New insights into the natural history of hepatitis $\mathrm{E}$ virus infection through a longitudinal study of multitransfused immunocompetent patients in France. J Viral Hepat 23: 569-575.

* Shouval D. 2018. Immunization against hepatitis A. Cold Spring Harb Perspect Med doi: 10.1101/cshperspect. a031682.

Shrestha MP, Scott RM, Joshi DM, Mammen MP Jr, Thapa GB, Thapa N, Myint KS, Fourneau M, Kuschner RA Shrestha SK, et al. 2007. Safety and efficacy of a recombinant hepatitis E vaccine. N Engl J Med 356: 895-903.

Shrestha AC, Seed CR, Flower RL, Rooks KM, Keller AJ, Harley RJ, Chan HT, Holmberg JA, Faddy HM. 2014. Hepatitis E virus and implications for blood supply safety, Australia. Emerg Infect Dis 20: 1940-1942.

Shrestha AC, Flower RL, Seed CR, Keller AJ, Harley R, Chan HT, Hoad V, Warrilow D, Northill J, Holmberg JA, et al. 2016a. Hepatitis E virus RNA in Australian blood donations. Transfusion 56: 3086-3093.

Shrestha AC, Flower RL, Seed CR, Rajkarnikar M, Shrestha SK, Thapa U, Hoad VC, Faddy HM. 2016b. Hepatitis E virus seroepidemiology: A post-earthquake study among blood donors in Nepal. BMC Infect Dis 16: 707.

Siripanyaphinyo U, Boon-Long J, Louisirirotchanakul S, Takeda N, Chanmanee T, Srimee B, Namsai A, Pounsawat P, Khupulsap K. 2014. Occurrence of hepatitis E virus infection in acute hepatitis in Thailand. J Med Virol 86: $1730-1735$.

Slot E, Hogema BM, Riezebos-Brilman A, Kok TM, Molier M, Zaaijer HL. 2013. Silent hepatitis E virus infection in Dutch blood donors, 2011 to 2012. Euro Surveill 18: 20550.

Slot E, Zaaijer HL, Molier M, Van den Hurk K, Prinsze F, Hogema BM. 2017. Meat consumption is a major risk factor for hepatitis E virus infection. PLOS ONE 12: e0176414.

Smith DB, Becher P, Bukh J, Gould EA, Meyers G, Monath T, Muerhoff AS, Pletnev A, Rico-Hesse R, Stapleton JT, et al. 2016. Proposed update to the taxonomy of the genera Hepacivirus and Pegivirus within the Flaviviridae family. J Gen Virol 97: 2894-2907.

Stramer SL, Moritz ED, Foster GA, Ong E, Linnen JM, Hogema BM, Mak M, Chia CP, Dodd RY. 2016. Hepatitis E virus: Seroprevalence and frequency of viral RNA detection among US blood donors. Transfusion 56: 481-488.

Su YY, Huang SJ, Guo M, Zhao J, Yu H, He WG, Jiang HM, Wang YJ, Zhang XF, Cai JP, et al. 2017. Persistence of antibodies acquired by natural hepatitis $\mathrm{E}$ virus infection and effects of vaccination. Clin Microbiol Infect 23: 336. e1-336.e4.

Tabatabai J, Wenzel JJ, Soboletzki M, Flux C, Navid MH, Schnitzler P. 2014. First case report of an acute hepatitis E subgenotype 3 c infection during pregnancy in Germany. J Clin Virol 61: 170-172.

Takahashi M, Kusakai S, Mizuo H, Suzuki K, Fujimura K, Masuko K, Sugai Y, Aikawa T, Nishizawa T, Okamoto H 2005. Simultaneous detection of immunoglobulin A (IgA) and IgM antibodies against hepatitis E virus (HEV) is highly specific for diagnosis of acute HEV infection. J Clin Microbiol 43: 49-56.

Takahashi M, Tanaka T, Takahashi H, Hoshino Y, Nagashima S, Jirintai, Mizuo H, Yazaki Y, Takagi T, Azuma $\mathrm{M}$, et al. 2010. Hepatitis E virus (HEV) strains in serum samples can replicate efficiently in cultured cells despite the coexistence of HEV antibodies: Characterization of HEV virions in blood circulation. J Clin Microbiol 48: 1112-1125.

Tam AW, Smith MM, Guerra ME, Huang CC, Bradley DW, Fry KE, Reyes GR. 1991. Hepatitis E virus (HEV): Molecular cloning and sequencing of the full-length viral genome. Virology 185: 120-131.

Tamada Y, Yano K, Yatsuhashi H, Inoue O, Mawatari F, Ishibashi H. 2004. Consumption of wild boar linked to cases of hepatitis E. J Hepatol 40: 869-870.

Tamura A, Shimizu YK, Tanaka T, Kuroda K, Arakawa Y, Takahashi K, Mishiro S, Shimizu K, Moriyama M. 2007. Persistent infection of hepatitis $\mathrm{E}$ virus transmitted by blood transfusion in a patient with T-cell lymphoma. Hepatol Res 37: 113-120.

Tedder RS, Ijaz S, Kitchen A, Ushiro-Lumb I, Tettmar KI, Hewitt P, Andrews N. 2017. Hepatitis E risks: Pigs or blood-That is the question. Transfusion 57: 267-272. 
H.R. Dalton and J. Izopet

Tei S, Kitajima N, Takahashi K, Mishiro S. 2003. Zoonotic transmission of hepatitis E virus from deer to human beings. Lancet 362: 371-373.

Teshale EH, Grytdal SP, Howard C, Barry V, Kamili S, Drobeniuc J, Hill VR, Okware S, Hu DJ, Holmberg SD. 2010 Evidence of person-to-person transmission of hepatitis $\mathrm{E}$ virus during a large outbreak in Northern Uganda. Clin Infect Dis 50: 1006-1010.

Thom K, Gilhooly P, McGowan K, et al. 2018. HEV in Scotland: Evidence of recent increase in viral circulation in humans. Eurosurveillance (in press).

Tremeaux P, Lhomme S, Chapuy-Regaud S, Peron JM, Alric L, Kamar N, Izopet J, Abravanel F. 2016. Performance of an antigen assay for diagnosing acute hepatitis $\mathrm{E}$ virus genotype 3 infection. J Clin Virol 79: 1-5.

Vollmer T, Diekmann J, Johne R, Eberhardt M, Knabbe C, Dreier J. 2012. Novel approach for detection of hepatitis $\mathrm{E}$ virus infection in German blood donors. J Clin Microbiol 50: $2708-2713$.

Vollmer T, Diekmann J, Eberhardt M, Knabbe C, Dreier J. 2016a. Hepatitis E in blood donors: Investigation of the natural course of asymptomatic infection, Germany, 2011. Euro Surveill doi: 10.2807/1560-7917.ES.2016.21. 35.30332.

Vollmer T, Diekmann J, Eberhardt M, Knabbe C, Dreier J 2016b. Monitoring of anti-hepatitis E virus antibody seroconversion in asymptomatically infected blood donors: Systematic comparison of nine commercial anti-HEV IgM and IgG assays. Viruses 8: E232.

Vollmer T, Knabbe C, Dreier J. 2016c. Knowledge is safety: The time is ripe for hepatitis $\mathrm{E}$ virus blood donor screening. Transfus Med Hemother 43: 425-427.

Wen GP, Tang ZM, Yang F, Zhang K, Ji WF, Cai W, Huang SJ, Wu T, Zhang J, Zheng ZZ, et al. 2015. A valuable antigen detection method for diagnosis of acute hepatitis E. J Clin Microbiol 53: 782-788.

Wenzel JJ, Preiss J, Schemmerer M, Huber B, Jilg W. 2013. Test performance characteristics of Anti-HEV IgG assays strongly influence hepatitis E seroprevalence estimates. J Infect Dis 207: 497-500.
Wichmann O, Schimanski S, Koch J, Kohler M, Rothe C, Plentz A, Jilg W, Stark K. 2008. Phylogenetic and casecontrol study on hepatitis E virus infection in Germany. $J$ Infect Dis 198: 1732-1741.

Xu C, Wang RY, Schechterly CA, Ge S, Shih JW, Xia NS, Luban NL, Alter HJ. 2013. An assessment of hepatitis E virus (HEV) in US blood donors and recipients: No detectable HEV RNA in 1939 donors tested and no evidence for HEV transmission to 362 prospectively followed recipients. Transfusion 53: 2505-2511.

Yapa CM, Furlong C, Rosewell A, Ward KA, Adamson S, Shadbolt C, Kok J, Tracy SL, Bowden S, Smedley EJ, et al. 2016. First reported outbreak of locally acquired hepatitis E virus infection in Australia. Med J Aust 204: 274.

Yin X, Ambardekar C, Lu Y, Feng Z. 2016. Distinct entry mechanisms for nonenveloped and quasi-enveloped hepatitis E viruses. J Virol 90: 4232-4242.

Yunoki M, Tanaka H, Takahashi K, Urayama T, Hattori S, Ideno S, Furuki R, Sakai K, Hagiwara K, Ikuta K. 2016. Hepatitis E virus derived from different sources exhibits different behaviour in virus inactivation and/or removal studies with plasma derivatives. Biologicals 44: 403-411.

Zaaijer HL. 2015. No artifact, hepatitis E is emerging. Hepatology 62: 654 .

Zaaijer HL, Yin MF, Lelie PN. 1992. Seroprevalence of hepatitis $\mathrm{E}$ in The Netherlands. Lancet 340: 681.

Zhang J, Zhang XF, Huang SJ, Wu T, Hu YM, Wang ZZ, Wang H, Jiang HM, Wang YJ, Yan Q, et al. 2015. Longterm efficacy of a hepatitis E vaccine. N Engl J Med 372: 914-922.

Zhao C, Geng Y, Harrison TJ, Huang W, Song A, Wang Y. 2015. Evaluation of an antigen-capture EIA for the diagnosis of hepatitis E virus infection. J Viral Hepat 22: 957963.

Zhu FC, Zhang J, Zhang XF, Zhou C, Wang ZZ, Huang SJ, Wang H, Yang CL, Jiang HM, Cai JP, et al. 2010. Efficacy and safety of a recombinant hepatitis $\mathrm{E}$ vaccine in healthy adults: A large-scale, randomised, doubleblind placebo-controlled, phase 3 trial. Lancet 376: 895-902. 


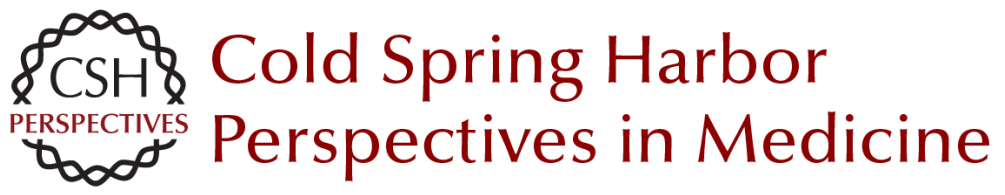

\section{Transmission and Epidemiology of Hepatitis E Virus Genotype 3 and 4 Infections}

Harry R. Dalton and Jacques Izopet

Cold Spring Harb Perspect Med 2018; doi: 10.1101/cshperspect.a032144 originally published online March 12, 2018

Subject Collection Enteric Hepatitis Viruses

Hepatitis A Virus Genome Organization and

Replication Strategy

Kevin L. McKnight and Stanley M. Lemon

Adaptive Immune Responses in Hepatitis A Virus and Hepatitis E Virus Infections Christopher M. Walker

Small Animal Models of Hepatitis E Virus Infection Tian-Cheng Li and Takaji Wakita

Acute and Persistent Hepatitis E Virus Genotype 3 and 4 Infection: Clinical Features, Pathogenesis, and Treatment

Nassim Kamar and Sven Pischke

Epidemiology of Genotype 1 and 2 Hepatitis E

Virus Infections

Kenrad E. Nelson, Alain B. Labrique and Brittany L. Kmush

History of the Discovery of Hepatitis A Virus Stephen M. Feinstone

Epidemiology and Transmission of Hepatitis A Virus and Hepatitis E Virus Infections in the United States

Megan G. Hofmeister, Monique A. Foster and Eyasu $\mathrm{H}$. Teshale

Stem Cell-Derived Culture Models of Hepatitis E

Virus Infection

Viet Loan Dao Thi, Xianfang Wu and Charles M. Rice
Evolutionary Origins of Enteric Hepatitis Viruses Anna-Lena Sander, Victor Max Corman, Alexander N. Lukashev, et al.

Enterically Transmitted Non-A, Non-B Hepatitis and the Discovery of Hepatitis E Virus Stanley M. Lemon and Christopher M. Walker

Natural History, Clinical Manifestations, and

Pathogenesis of Hepatitis E Virus Genotype 1 and 2 Infections

Rakesh Aggarwal and Amit Goel

Hepatitis A Virus and Hepatitis E Virus: Emerging and Re-Emerging Enterically Transmitted

Hepatitis Viruses

Stanley M. Lemon and Christopher M. Walker

Hepatitis A Virus Capsid Structure

David I. Stuart, Jingshan Ren, Xiangxi Wang, et al.

Comparative Pathology of Hepatitis A Virus and

Hepatitis E Virus Infection John M. Cullen and Stanley M. Lemon

Innate Immunity to Enteric Hepatitis Viruses Zongdi Feng and Stanley M. Lemon

Nonhuman Primate Models of Hepatitis A Virus and Hepatitis E Virus Infections

Robert E. Lanford, Christopher M. Walker and Stanley M. Lemon

For additional articles in this collection, see http://perspectivesinmedicine.cshlp.org/cgi/collection/ 